\title{
Investigation of Capital Market Efficiency in Indonesia
}

\author{
Gita Masria Hutapea ${ }^{1 *}$, Ahmad Fauzan Fathoni ${ }^{2}$, and Yulia Efni ${ }^{3}$ \\ 1,2,3 Universitas Riau, Pekanbaru, Indonesia
}

\begin{abstract}
In the midst of a national economic growth downturn that affected the capital market as a subsystem of the economy, now Indonesia capital market industry began to look at the development of the application of the principles of sharia as an alternative investment instruments in capital markets activities in Indonesia. The growth of the Islamic capital market in Indonesia is quite encouraging, but the Islamic capital market exposure is still minimal. Lack of public understanding about the Islamic capital market into doubt for investors to invest in the capital market. With the background of the problem, this research aims to investigate the level of efficiency increase of capital markets in Indonesia to see the influence of the capital market and the asymmetry of information on abnormal return. The population in this study are all listed company listed on the Stock Exchange 2014-2018 period as many as 626 companies with a total sample of 238 companies were selected based on criteria predetermined. The analytical method used in this research is multiple linear regression and the results showed that the type of capital markets significant negative effect on abnormal returns and the information asymmetry significant positive effect on abnormal returns. The continued development of the Islamic capital market information asymmetry and abnormal returns are also lower so the efficiency of the capital market has also increased. The analytical method used in this research is multiple linear regression and the results showed that the type of capital markets significant negative effect on abnormal returns and the information asymmetry significant positive effect on abnormal returns. The continued development of the Islamic capital market information asymmetry and abnormal returns are also lower so the efficiency of the capital market has also increased. The analytical method used in this research is multiple linear regression and the results showed that the type of capital markets significant negative effect on abnormal returns and the information asymmetry significant positive effect on abnormal returns. The continued development of the Islamic capital market information asymmetry and abnormal returns are also lower so the efficiency of the capital market has also increased.
\end{abstract}

Keywords: Abnormal Return, Principles of Islamic Shariah, The Information Asymmetry, The Type of Capital Markets

\section{Introduction}

The existence of capital market in Indonesia is one of the most important factors in helping to build a strong national economy and global competitiveness with the availability of facilities and the Indonesian capital market instruments that can compete with the capital market instruments other countries. In connection with that, amid the deterioration of national economic growth rate, which also affected the capital market sector as a subsystem of national economy of Indonesia, now the Indonesian capital market industry began to look at the development of the application of the principles of Islamic Shari'a as an alternative investment instruments in capital market activities in Indonesia.

* Corresponding author. Email address: hutapeagita16@gmail.com 
Research conducted by Ngo \& Wijayanti (2003) concluded that that invest in Islamic stocks more profitable than investing in shares of non-Islamic. Ocean et al (2016) concluded that the Islamic stock index in the Indonesia Stock Exchange is an efficient capital market in the form of a strong half. Research conducted by Khajar (2012) found that the Indonesian Islamic capital market is efficient at least in the form of weak. Study conducted by Nasution (2015) showed that the Islamic capital market has been in a semi-strong efficient.

Research on the conventional capital market conducted by Mar'ati (2012) concluded that that the Indonesian capital market efficiency theory for semi-strong form (semi-strong form) has been efficient. Dwipayana \& Wiksuana (2017) concluded that the Indonesia Stock Exchange, represented by compass 100 index is expressed in a semi-strong efficient in information (informationnaly efficient market).

Research on the comparative efficiency of Islamic capital markets and capital markets conventionally performed by Ali et al. (2018) using MF-DFA analysis concludes that the Islamic capital market is more efficient than the conventional capital market. Research Mensi et al (2016) on the efficiency of the Islamic capital market after the GFC using MF-DFA analysis shows that the Islamic capital market more efficient in the long run than in the short term.

Despite the growth of the Islamic capital market is quite encouraging, but the Islamic capital market exposure is still minimal. Lack of public understanding about the Islamic capital market into doubt for investors to invest in the capital market. This is because the practice of activity in the capital market that contain the element of speculation. Therefore, requires knowledge of the Islamic capital market, both of concepts and principles, as well as trade mechanisms. With the background of the problem, This study aimed to investigate the level of efficiency increase of capital markets in Indonesia to see the influence of the capital market and the asymmetry of information on abnormal return Based on the data that has been analyzed, the type of capital markets significant negative effect on abnormal returns and the information asymmetry significant positive effect on abnormal returns. This suggests that the development of the Islamic capital market information asymmetry and the lower abnormal returns so that the efficiency of the capital market has also increased.

Furthermore, the explanation in this article will be divided into three parts, the first is a literature review that will explain any theory used in this study and previous research that referenced researcher. The second part is the results and discussion will explain the results of research and discussion of results have been found. Then, the third part is the conclusion that a more concise outline of the research study.

\section{Literature Study/Hypothesis Development Information Asymmetry Theory}

This theory says that the parties associated with the company do not have the same information about the prospects and risks of the company. Certain parties have more information than others. This theory consists of theories:

\section{Myers and Majluf}

According to this theory there is information asymmetry between managers and outsiders. The manager has more complete information about the condition of the company than outsiders.

\section{Signaling}

Signaling develops a model in which the capital structure (the use of debt) is a signal delivered by managers to the market. If the manager has confidence that the company's prospects are good, and therefore wants the shares to increase, he wants to communicate this to investors. Managers can use more debt as a more credible signal. 


\section{Islamic Capital Market Concept}

The principles of Islamic capital market instruments differ from conventional capital markets. Shares traded on the Islamic capital market must come from issuers that meet the Islamic criteria

The Sharia capital market must be free from unethical and moral transactions, such as insider trading and short selling. Therefore, the Islamic capital market must throw away any transactions that contain elements of speculation. This is what distinguishes it from conventional capital markets which is one way to get its benefits by using speculation. (Sholahuddin, 2006).

\section{Effect of Capital Market Types on Abnormal Returns}

The concept of an efficient market places more emphasis on aspects of information where the price of traded securities has reflected all available information (Tandelilin, 2010). Based on this concept, efficient markets are always associated with the availability of information which means there is no asymmetric information among stakeholders.

According to the asymmetry theory, there is an imbalance of information between stakeholders relating to the prospects and risks of companies where certain parties have better information than outside parties (Hanafi, 2014). More information that is owned by the manager can trigger to take actions in accordance with the wishes and interests to maximize the utility for himself.

Conceptually, the Islamic capital market is designed to reduce asymmetric information. This is supported by Sutedi's research (2011) which states that the existence of Islamic capital market rules aims to minimize and even eliminate speculation in stock trading, where in conventional capital markets speculation is a very difficult situation to separate. In accordance with the concept, the Islamic capital market should be more efficient compared to conventional capital markets. The efficiency referred to here means that no investor can get an abnormal return in stock trading. Based on the description above, the research hypothesis can be formulated as follows.

H1: Suspected type of capital market affects abnormal returns.

\section{Effect of Information Asymmetry on Abnormal Return}

An efficient capital market is needed to eliminate speculative actions because all information is the basis of investors in making investment decisions. The impact of an efficient market is that no investor can control the market. With the efficiency of the capital market, it means that no one can get an abnormal return. In addition, if the market is efficient, there is no asymmetric information. Information asymmetry is a condition where there is an imbalance of information between management and shareholders (Irfan, 2002).

According Jogiyanto (2013) information asymmetry is private information that is only owned by investors who have information (informed investors). Information asymmetry indicates that there is a group of investors who have more information about an event that allows investors to get abnormal returns. The higher the information asymmetry, the higher the likelihood that investors will get an abnormal return which results in an inefficient market.

H2: Alleged information asymmetry affects abnormal returns.

\section{Research Methods}

The population in this study are all listed company listed on the Stock Exchange 2014-2018 period as many as 626 companies. The sampling technique that has been chosen is purposive sampling method with a total sample of 238 . The analysis method used in this research is multiple linear regression 
Data used in this research is secondary data. Secondary data sources in this study was obtained from the Indonesia Stock Exchange through the sitewww.idx.co.id, www.investing.comand www.yahoofinance.com,

\section{Operational Definition and Measurement of VariablesAbnormal Return}

According Husnan (2009) abnormal return is the difference between the actual profit rate to the level of the expected profit. According Jogiyanto (2013) return is not normal (abnormal return) is the difference between actual returns that occurred with the return expectations. The formula to calculate the abnormal return by Jogiyanto (2013), namely:

$$
\mathrm{RTNi}, \mathrm{t}=\mathrm{Ri}, \mathrm{t}-\mathrm{E}[\mathrm{Ri}, \mathrm{t}]
$$

\section{Type Capital Markets}

Type capital market is divided into two, namely the Islamic capital market and conventional capital markets. General differences between conventional capital market with the Islamic capital market can be seen in the instruments and mechanisms of the transaction, while the Islamic stock index value difference with conventional stock index value lies in the issuer's shares of criteria that must meet the fundamental principles of sharia.

In this study, the Islamic capital market rated 1 and the conventional capital market by value 0 .

\section{Asymmetry of Information}

Asymmetry of information is a condition where there is an imbalance between the management information acquisition as a provider of information to the shareholders and stakeholders as the user information (Irfan, 2002).

Asymmetry information can be measured by using the bid ask spread. Bid ask spread can be measured by the following formula:

$$
\text { SPREADi, } \mathrm{t}=\frac{\left(a s k_{i, t}-b i d_{i, t}\right.}{\left\{\left(a s k_{i, t}+b i d_{i t}\right) / 2\right\}} \times 100
$$

\section{Results}

\section{Descriptive Statistics Analysis}

A description of the variables of this study are presented in Table descriptive statistics which show the minimum, maximum, mean, and standard deviation can be seen in this betikut table.

Table 1 Descriptive Statistics Test Results ISSI VS JCI descriptive Statistics

\begin{tabular}{|l|c|c|c|c|c|}
\hline & $\mathrm{N}$ & Minimum & Maximum & mean & $\begin{array}{c}\text { Std. } \\
\text { deviation }\end{array}$ \\
\hline Type Capital Markets & 276891 & 0 & 1 & .96 & .195 \\
Information asymmetry & 276891 & .000 & 39316 & 3.4160 & 3.269144 \\
abnormal Return & 276891 & -3131 & 3,843 & -.05229 & .965581 \\
\hline
\end{tabular}

Source: Data processed (2019)

Table 2 Test Results Descriptive Statistics JII VS LQ45

\begin{tabular}{|c|c|c|c|c|c|}
\hline & $\mathrm{N}$ & Minimum & Maximum & mean & Std. deviation \\
\hline $\begin{array}{l}\text { type capital market } \\
\text { Information asymmetry } \\
\text { abnormal Return }\end{array}$ & $\begin{array}{l}42596 \\
42596 \\
42596\end{array}$ & $\begin{array}{c}0 \\
.132 \\
-9270\end{array}$ & $\begin{array}{c}1 \\
27435 \\
15364\end{array}$ & $\begin{array}{c}.38 \\
2.72883 \\
.00748\end{array}$ & $\begin{array}{c}.484 \\
1.665304 \\
2.915783\end{array}$ \\
\hline
\end{tabular}
descriptive Statistics

Source: Data processed (2019) 


\section{Classical Assumption Test Results \\ Normality test}

The test results normality of the data in this study can be seen in Table 3 and 4 below.

Table 3 Normality Test Results ISSI VS JCI

One-Sample Kolmogorov-Smirnov Test

\begin{tabular}{|ll|c|}
\hline & & $\begin{array}{c}\text { Residual } \\
\text { unstandardized }\end{array}$ \\
\hline $\mathrm{N}$ & Mean & 276891 \\
Normal & Std. & .0000000 \\
Parametersa, b & Deviation & .76003491 \\
& Absolute & .406 \\
Most Extreme & Positive & .040 \\
Differences & Negative & -.046 \\
Kolmogorov-Smirnov Z & .046 \\
Asymp. Sig. (2-tailed) & $.063 \mathrm{C}$ \\
\hline
\end{tabular}

a. Test distribution is Normal.

b. Calculated from data.

Source: Data processed (2019)

\section{Table 4 Normality Test Results JII VS LQ45}

One-Sample Kolmogorov-Smirnov Test

\begin{tabular}{|ll|c|}
\hline & & $\begin{array}{c}\text { Residual } \\
\text { unstandardized }\end{array}$ \\
\hline $\mathrm{N}$ & Mean & 42596 \\
Normal & Std. & 2.18187630 \\
Parametersa, b & Deviation & \\
& Absolute & .105 \\
Most Extreme & Positive & .086 \\
Differences & Negative & -.105 \\
Kolmogorov-Smirnov Z & .105 \\
Asymp. Sig. (2-tailed) & $.072 \mathrm{C}$ \\
\hline
\end{tabular}

a. Test distribution is Normal.

b. Calculated from data.

Source: Data processed (2019)

Based on the tables 3 and 4 above shows the value Asimp. Sig. Using data ISSI JCI VS 0.063>0.05. Furthermore, using the data JII LQ45 VS 0.072>0.05. These results indicate that the regression model to meet the normal assumptions.

\section{Test Multicollinearity}

The test results multicollinearity in this study are presented in Table 5 and 6 below.

Table 5 Test Results Multicollinearity ISSI VS JCI

Coefficients

\begin{tabular}{|l|r|r|}
\hline \multicolumn{1}{|c|}{ Model } & \multicolumn{2}{|c|}{ collinearity Statistics } \\
\cline { 2 - 3 } & Tolerance & \multicolumn{1}{c|}{ VIF } \\
\hline (Constant) & & \\
Type Capital Markets & .992 & 1,008 \\
Information asymmetry & .992 & 1,008 \\
\hline
\end{tabular}

a. Dependent Variable: Abnormal_Return

Source: Data processed (2019) 
Table 6 Test Results Multicollinearity ISSI VS JCI

Coefficients

\begin{tabular}{|l|r|c|}
\hline \multicolumn{1}{|c|}{ Model } & \multicolumn{2}{|c|}{ collinearity Statistics } \\
\cline { 2 - 3 } & Tolerance & VIF \\
\hline (Constant) & .999 & 1,001 \\
Type Capital & & 1,001 \\
Markets & .999 & \\
Information & & \\
\hline
\end{tabular}

a. Dependent Variable: Abnormal_Return

Source: Data processed (2019)

Based on the results in Table 5 and 6 above can be seen that the four variables independem have tolerance values $>0.10$ and VIF $<10$, so that it can be concluded that the regression model is free of multicollinearity.

\section{Test Heteroskidastity}

Heteroskidastity testing results in this study are presented in Table 7 and 8 below.

Table 7 Test Results Heteroskedasticity ISSI VS JCI Coefficients

\begin{tabular}{|c|c|c|}
\hline Model & $\mathrm{T}$ & Sig. \\
\hline (Constant) & & \\
\hline $\begin{array}{l}\text { Type Capital } \\
\text { Markets }\end{array}$ & .231 & .641 \\
\hline $\begin{array}{l}\text { Information } \\
\text { asymmetry }\end{array}$ & .759 & .789 \\
\hline
\end{tabular}

a. Dependent Variable: Res_2

Source: Data processed (2019)

According to the table 7 can be seen that the Sig. for variable types of capital market amounted to $0,641>0,05$ and the information asymmetry $0.789>0.05$, so it can not happen heteroskedastisity concluded in this study.

Table 8 Test Results heterocedastisity JII VS LQ45 Coefficients

\begin{tabular}{|l|c|c|}
\hline \multicolumn{1}{|c|}{ Model } & $\mathrm{T}$ & Sig. \\
\hline $\begin{array}{l}\text { (Constant) } \\
\begin{array}{l}\text { Type Capital } \\
\text { Markets }\end{array}\end{array}$ & -.324 & .774 \\
$\begin{array}{l}\text { Information } \\
\text { asymmetry }\end{array}$ & .652 & .889 \\
\hline
\end{tabular}

a. Dependent Variable: Res_2

Source: Data processed (2019)

Based on table 8 above it can be seen that the Sig. for variable types of capital market amounted to $0.774>0.05$ and the information asymmetry $0.889>0.05$, so it can not happen heteroskedastisity concluded in this study.

\section{Autocorrelation Test}

Autocorrelation test results of this research can be seen in table 9 and 10 below: 
Table 9 Test Results autocorrelation ISSI VS JCI Model Summary

\begin{tabular}{|c|c|c|c|c|c|}
\hline Model & $\mathrm{R}$ & R Square & Adjusted R Square & Std. Error of the Estimate & Durbin-Watson \\
\hline 1 & $.617 \mathrm{a}$ & .380 & .380 & .760038 & .366 \\
\hline
\end{tabular}

a. Predictors: (Constant), Asimetri_Informasi, Jenis_Pasar_Modal

b. Dependent Variable: Abnormal_Return

Source: Data processed (2019)

According to the table 9 the value of Durbin Watson (DW) produced a regression model that is equal to 0.366 while for the table DW with sampael $\mathrm{N}=276891$ and a variable indevendennya $(\mathrm{k})=2$ values obtained $\mathrm{dL}=0.181$ and $\mathrm{dU}=0.223$. Thus $\mathrm{dU}$ $<\mathrm{DW}<4-\mathrm{dU}=0.223<0.366<3.777$, it can be concluded in this study there is no positive or negative autocorrelation.

Table 10 Test Results Autocorrelation JII VS LQ45

Model Summary

\begin{tabular}{|c|c|c|c|c|c|}
\hline Model & $\mathrm{R}$ & $\mathrm{R}$ Square & $\begin{array}{c}\text { Adjusted } \\
\mathrm{R} \text { Square }\end{array}$ & Std. Error of the Estimate & Durbin-Watson \\
\hline 1 & $.663 \mathrm{a}$ & .440 & .440 & 2.181928 & 0404 \\
\hline
\end{tabular}

a. Predictors: (Constant), Asimetri_Informasi, Jenis_Pasar_Modal

b. Dependent Variable: Abnormal_Return

Source: Data processed (2019)

According to the table above can be seen 10 Durbin Watson value of 0.404 . As for the value DW table with sampael $\mathrm{N}=42596$ and variable indevendennya $(\mathrm{k})=2$ values obtained $\mathrm{dL}=0.336$ and $\mathrm{dU}=0.378$. Thus $\mathrm{dU}<\mathrm{DW}<4-\mathrm{Du}=0.378<0.404$ $<3.596$, it can be concluded in this study there is no positive or negative autocorrelation.

\section{Test The coefficient of determination (R2 Test)}

Test Results The coefficient of determination can be seen in table 11 below.

Table 11 Test Results The coefficient of determination (R2) ISSI VS JCI Model Summary

\begin{tabular}{|c|c|c|c|c|c|}
\hline Model & $\mathrm{R}$ & $\mathrm{R}$ Square & Adjusted R Square & Std. Error of the Estimate & Durbin-Watson \\
\hline 1 & $.617 \mathrm{a}$ & .380 & .380 & .760038 & .366 \\
\hline
\end{tabular}

a. Predictors: (Constant), Asimetri_Informasi, Jenis_Pasar_Modal

b. Dependent Variable: Abnormal_Return

Source: Data processed (2019)

Based on the test results of the coefficient of determination ISSI VS JCI in the table above, the value of $\mathrm{R}$ square in the regression model obtained at 0.380 . This shows that the influence of the independent variables and the type of capital market information asymmetry to the dependent variable abnormal return can be explained by this equation at $38 \%$ while $62 \%$ are influenced by other factors not included in this regression model.

Furthermore, the value of R square using VS JII LQ45 index data can be seen in Table 12 below: 
Table 12 Test Results The Coefficient of Determination (R2) VS JII LQ45 Model Summary

\begin{tabular}{|c|c|c|c|c|c|}
\hline Model & $\mathrm{R}$ & R Square & Adjusted R Square & Std. Error of the Estimate & Durbin-Watson \\
\hline 1 & $.663 \mathrm{a}$ & .440 & .440 & 2.181928 & .404 \\
\hline
\end{tabular}

a. Predictors: (Constant), Asimetri_Informasi, Jenis_Pasar_Modal

b. Dependent Variable: Abnormal_Return

$$
\text { Source: Data processed, (2019) }
$$

Based on the test results of the coefficient of determination JII VS LQ45 in the table above, the value of $\mathrm{R}$ square in the regression model obtained at 0.440 . This shows that the influence of the independent variables and the type of capital market information asymmetry to the dependent variable abnormal return can be explained by this equation by $44 \%$, while $56 \%$ are influenced by other factors not included in this regression model.

\section{Simultaneous Effect Test (F Test)}

Table 13 Test F Results ISSI VS JCI ANOVAa

\begin{tabular}{|l|l|c|c|}
\hline Model & & \multicolumn{1}{|c|}{ F } & Sig. \\
\hline \multirow{3}{*}{1} & Regression & 85008.125 & $.000 \mathrm{~b}$ \\
\cline { 2 - 4 } & Residual & & \\
\cline { 2 - 4 } & Total & & \\
\hline
\end{tabular}

Source: Data processed (2019)

Table 14 Test F Results JII VS LQ45 ANOVAa

\begin{tabular}{|c|l|c|c|}
\hline Model & & F & Sig. \\
\hline 1 & Regression & 16736.308 & $.000 \mathrm{~b}$ \\
\cline { 2 - 4 } & Residual & & \\
\cline { 2 - 4 } & Total & & \\
\hline
\end{tabular}

Source: Data processed (2019)

From the above table F test both JCI and JII ISSI VS VS LQ45 known that the variable types of capital market and asymmetry inforrmasi have a significance value of 0.000 . With a degree of confidence of $95 \%$ or $5 \%$ significance level, it can be seen that the value of the significance of 0000 is less than the alpha value of 0:05. Thus it is known that the independent variables jointly significant effect on the dependent variable.

\section{Partial test ( $t$ test)}

Table 15 Test Results t ISSI VS JCI Coefficients

\begin{tabular}{|c|c|c|c|}
\hline \multicolumn{2}{|r|}{ Model } & $\mathrm{T}$ & Sig. \\
\hline 1 & (Constant) & -55449 & .000 \\
\hline & Type Capital Markets & -38203 & .000 \\
\hline & Information asymmetry & 412328 & .000 \\
\hline
\end{tabular}

a. Dependent Variable: Abnormal Return

Source: Data processed (2019) 
Table 16 Test Results t JII VS LQ45

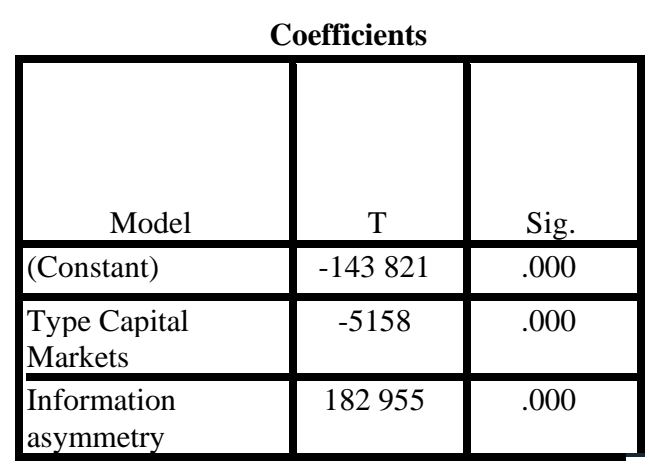

a. Dependent Variable: Abnormal Return

Source: Data processed (2019)

\section{Discussion}

\section{Effect of Capital Markets type to Abnormal Return}

Well known significance values using ISSI Data JCI and JII VS VS LQ45 \$ 0.00 . 0.000 significance value $<0.05$ then $\mathrm{H} 1$ is accepted, so that it can be concluded that the type of capital markets significant negative effect on abnormal returns.

The statistical results of research using data ISSI VS CSPI index shows that the type of capital markets significant negative effect on abnormal returns. The negative sign means that the development of the Islamic capital market abnormal return will be lower. In accordance with theIslamic capital market concept which states that the Islamic capital market is made to reduce the asymmetry of information which the shares traded should come from companies engaged in sectors that meet the criteria of sharia and free from elements of usury, as well as stock transactions carried out by avoiding speculation practices.

True Islamic capital market must be free of transactions that are unethical and immoral, such as insider trading and short selling. Therefore, the Islamic capital market should throw away any transaction that contains elements of speculation. This is what distinguishes it from conventional capital market which is one way to get the benefits by using speculation. Although it acknowledged, in certain cases such as insider trading and market manipulation by making false statements prohibited in conventional capital markets (Sholahuddin, 2006).

The results are consistent with research conducted by Khajar (2012) also said that the Indonesian Sharia capital market is efficient in the weak form. Furthermore Ocean et al (2016) concluded that the Islamic stock index in the Indonesia Stock Exchange is an efficient capital market in the form of a strong half.

Results of research conducted outside Indonesia also supports that such research Ali et al (2018) and Mensi et al (2016) which states that the Islamic capital market more efficient compared with the capital markets conventional.

Further visits are specifically using the index data with the best performance are JII VS LQ45 also so that that kind of capital markets negatively affect the abnormal return. This suggests that the development of the Islamic capital market abnormal return will be lower. This is supported by research Sutedi (2011) which stated that with the rules of the Islamic capital market aims to minimize or eliminate speculation in stock trading, where the conventional capital market speculation is very difficult to separate state. With these rules then the investor the opportunity to earn abnormal returns are also lower.

If conventional and sharia capital markets are applied together in Indonesia and other countries, it can increase capital market growth due to various choices that can be chosen by investors. If investors do not want their funds mixed with ribawi funds, 
investors can invest their capital in the Islamic capital market and conversely investors who do not want to invest in the Islamic capital market can invest in conventional capital markets. Different if in a country only applies one of the types of capital markets (conventional or sharia), then there is no choice for investors, thereby reducing the interest of investors to invest in the capital market. This will have an impact on the decline in capital market growth in Indonesia and other countries.

\section{Effect of Information Asymmetry on Abnormal Return}

Well known significance values using ISSI Data JCI and JII VS VS LQ45 \$ 0.00 . 0.000 significance value $<0.05$ then $\mathrm{H} 1$ is accepted, so that it can be concluded that the information asymmetry significant negative effect on abnormal returns.

The statistical results of research using data ISSI VS JCI showed that the asymmetry of information is positive and significant effect on the abnormal return. The positive sign means that the higher the information asymmetry abnormal returns will also be higher, conversely the lower the information asymmetry abnormal returns will also be lower.

Asymmetry theory says that the parties associated with the company does not have the same information about the company's prospects and risks. Certain parties have better information than the other party. Managers usually have better information than with outsiders (investors) because it can be said the case of information asymmetry between managers and investors.

More information is owned by the manager may trigger to perform actions in accordance with the wishes and interests of maximizing utility for himself. As for the owners of capital in this case the investor would be difficult to effectively control the actions taken by management because it has little information exists.

Managers as a manager of the company more aware of internal information and the company's prospects in the future compared to the owners (shareholders). Therefore, as a manager, the manager is obliged to give a signal about the state of the company to the owner. A given signal can be done through the disclosure of accounting information such as financial reports.

This study was supported by research Wardani et al (2016) which states that the information asymmetry significant positive effect on stock returns. Further research Yassin et al (2015) stated that the information asymmetry significant positive effect on stock returns. Other studies are Clinch and Lombardi (2011) states that the higher the information asymmetry abnormal returns are also higher.

The same results were obtained from the data more specific indices that use stock index with the best performance are JII VS LQ45 which states that the information asymmetry significant positive effect on abnormal return, Which means that the higher the information asymmetry abnormal returns will also be higher. Interestingly, with the growing development of the Islamic capital market information asymmetry will also be reduced due to the Islamic capital market is not allowed to practice speculation. With these rules then the asymmetry of information is also getting lower and cause the abnormal return is lower as well. The lower abnormal returns, the market is also more efficient.

\section{Conclusion}

Type capital markets significant negative effect on abnormal returns and information asymmetry significant positive effect on abnormal returns. 


\section{References}

Ali, et al. (2018). Stock Market Efficiency: A Comparative Analysis of Islamic and Conventional Stock Markets. www. elsevier.com/locate/physa. 03784371

Clinch., \& Lombardi. (2011). Information and the Cost of Capital: The Easley-O'Hara (2004), Model with endogenous information acquisition. Australian Journal of Management, 36(1), 5-14.

Dwipayana, I. G., \& Wiksuana, I. G. (2017). Market Efficiency Testing on the Exchange Indonesian Effect. Eud Management E-Journal, 6(4).

Hanafi, M. (2014). Financial Management ( $1^{\text {st }}$ Edition). Yogyakarta: BPFE

Husnan, S. (2009). Basics Securities Analysis and Portfolio Theory (4 ${ }^{\text {th }}$ Edition). Yogyakarta: UPP STIM YKPN

Irfan, A. (2002). Financial Reporting and Information Asymmetry in Relationships the Agency. Economic Track, 19.

Jogiyanto, H. (2013). Portfolio Theory and Investment Analysis. Yogyakarta: BPFE.

Kasmir. (2004). Banks and Other Financial Institutions. Jakarta: Sinar Grafika.

Khajar, I. (2012). Indonesian Islamic Capital Market Efficiency Before And After Global Financial Crisis of 2008. Journal of Finance and Banking, 16(1)

Mar'ati, F. S. (2012). Analysis of the Indonesian Capital Market Efficiency. Journal of Applied Management Sciences and Accounting, 3(2)

Mensi, et al. (2016). Global Financial Crisis And Weak Form Efficiency Of Islamic Sectoral Stock Markets: An MF-DFA Analysis. https://doi.org/10.016/j.physa. 12034

Nasution, Y. S. (2015). Efficient Market Hypothesis (Fama Theory According to the Capital Market and Islamic view). Journal of Economic Perpekstif Darussalam, $1(1)$

Ngo, A., \& Wijayanti, I. (2003). Fundamental Factor Analysis and Systematic Risk of Property Stock Prices on the JSE. Journals Accounting \& Finance, 5.

Ocean, et al. (2016). Capital Market Efficiency Analysis Sharia Stock Index in Indonesia Stock Exchange. Journal Katalogis, 4(6)

Sholahuddin. (2006). The Economic and Financial Institutions of Islam. Surakarta: Muhammadiyah University Press.

Sutedi, A. (2011). Syariah Capital Market Financial Investment Facility Based on Sharia Principles. Jakarta: Sinar Grafika.

Tandelilin, E. (2010). Portfolio and Investment Theory and Application ( $1^{\text {st }}$ Edition). Yogyakarta: Canisius

Wardani, et al. (2016). Effect of Information Asymmetry of Finance, IPO, Discretionary Accrual to the Stock Return Rate in Company Go Public (Empirical Study On Manufacturing Companies Listed on the Stock Exchange Period 2011-2015). Journal of the Faculty of Economics. 
AFEBI Management and Business Review (AMBR)

Vol.04 No.02, December 2019

Yassin, et al. (2015). The Relationship Between Information Asymmetry and Stockreturn in The Presence of Accounting Conservatism. International Journal of Business and Management, 10(5) 